\title{
PENGARUH TIMBAL BALIK ANTARA PEMBAYARAN DIVIDEN DAN PERTUMBUHAN MODAL SENDIRI PERUSAHAAN MANUFAKTUR DI BURSA EFEK INDONESIA
}

\author{
Sofiati \\ Yenni Kurnia Gusti \\ STIE Widya Wiwaha Yogyakarta \\ sofiatisubagio61@gmail.com
}

\begin{abstract}
This study extends previous research on dividend policy and funding decisions using structural equation modeling. Previous studies have focused on dividend policy or funding decisions alone, to determine the factors that influence by using multiple linear regression. This study aims to determine the mutual influence between dividends and capital growth. The authors would like to prove that there are similarities between the factors that affect the payment of dividends and capital growth include profitability,agency cost of debt, and retained earnings. In this research, the sample used is 72 shares activitely traded and has been listing between periods 2009-2013 in Indonesia Stock Exchange. The test results demonstrate the usefulness of the model testing using indicators overall goodness of fit to meet the criteria recomended level of fitness. By using the non-statistical measure such absolute goodness of fit and parsimony goodness of fit value exceeds recomended levels, it has indicated a good fit between the data with the model proposed research.
\end{abstract}

Keyword: payment of dividends, capital growth, profitability, agency cost of debt, retained earnings$$
\text { PENDAHULUAN }
$$

Laba yang diperoleh perusahaan yang sudah go public sebaiknya tidak dibagikan seluruhnya sebagai dividen karena sebagian harus disisihkan untuk dinvestasikan kembali yaitu sebagai retained earning. Semakin besar laba ditahan dari tahun ke tahun berarti semakin besar proporsi modal sendiri, berarti ada pertumbuhan modal sendiri. Semakin besar tingkat pertumbuhan modal sendiri berarti semakin kuat posisi keuangan perusahaan. Pada kebijakan dividen terdapat dua pihak yang berkepentingan dan yang saling bertentangan
\end{abstract}

yaitu: kepentingan pemegang saham dengan dividennya dan kepentingan perusahaan dengan retained earning-nya. Ada kepentingan pemegang obligasi yang dapat mempengaruhi besarnya dividen kas yang dibagikan. Besar kecilnya dividen kas yang dibagikan kepada pemegang saham tergantung pada kebijakan dividen masing-masing perusahaan sehingga pertimbangan manajemen sangat diperlukan (Levy dan Sarnat,1990).

Penelitian ini dilakukan dengan dorongan hasil studi yang dilakukan oleh Alli, Khan dan Ramirez (1985), Sugiarto (1997) dan Surwanti (1996) tentang dividen dan modal sendiri 
perusahaan. Penulis dalam penelitian ini hanya memfokuskan pada dividen kas. Dividen saham tidak diikut sertakan karena dividen saham bukanlah merupakan pendapatan bagi pemegang saham dengan alasan yang berbeda-beda. Mengingat pentingnya dividen bagi kelangsungan hidup perusahaan dan adanya sebagian laba yang tidak dibagikan atau ditahan sebagai sumber dana maka penulis bermaksud meneliti apakah beberapa faktor yang mempengaruhi kebijakan dividen dan beberapa faktor yang mempengaruhi pertumbuhan modal sendiri adalah sama sehingga terjadi hubungan timbal balik atau saling mempengaruhi antara faktor satu dengan faktor lainnya khususnya bagi industri manufaktur yang go public di Bursa Efek Indonesia. Maksud penelitian ini adalah menerapkan model analisis struktural Arbukle (1997), mengkonfirmasi teori bahwa ada kesamaan antara faktor-faktor yang mempengaruhi pembayaran dividen dan pertumbuhan modal sendiri. Bagi emiten hasil penelitian ini diharapkan dapat menjadi bahan pertimbangan dalam pengambilan keputusan dividen dan menentukan kebijakannya untuk mempercepat laju pertumbuhan modal sendiri sehingga dapat meningkatkan nilai perusahaan.

\section{REVIEW LITERATUR DAN HIPOTESIS}

\section{Keputusan Pendanaan}

Menurut Haugen (1990) satu-satunya cara perusahaan mentransfer kesejahteraan kepada pemegang saham adalah melalui pembayaran dividen. Walaupun ada indikasi di Bursa Efek bahwa setelah Swastanisasi (1992), investor lebih berorientasi pada capital gain, namun informasi mengenai dividen tetaplah diperlukan. Hal ini disebabkan karena salah satu faktor yang mempengaruhi harga saham adalah harapan investor terhadap tingkat pendapatan dan dividen yang akan datang (Van Horne, 1986). Menurut Haugen (1990) dikatakan bahwa dalam keputusan pembagian dividen, perusahaan harus mempertimbangkan kelangsungan hidup dan pertumbuhan perusahaannya. Keputusan pembelanjaan menyangkut tentang bagaimana membiayai kegiatan perusahaan, bagaimana memperoleh dana dengan biaya yang minimal serta komposisi sumber pembiayaan yang optimal. Empat sumber dana utama yang digunakan perusahaan untuk membelanjai operasi perusahaan antara lain utang, saham preferen, saham biasa, dan laba ditahan. Keempat sumber dana operasi perusahaan tersebut apabila dikelompokkan akan merupakan utang dan modal sendiri seperti yang dikemukakan oleh Laurens D Schall dan Charles W Halley (1983).

Adapun faktor-faktor yang mempengaruhi pertumbuhan modal sendiri dapat ditentukan dengan perumusan (Hopkin, 1973) sebagai berikut:

$$
G=f\left(R O A, \frac{D}{E}, i, t, b\right)
$$

Dimana:

ROA menunjukkan tingkat kemampuan perusahaan dalam menghasilkan laba dari aktiva yang dipergunakan. Sedangkan D/E menunjukkan kemampuan modal sendiri untuk memenuhi kewajibannya. Adapun $\mathrm{b}$ menunjukkan tingkat laba yang ditahan, I merupakan bunga hutang yang dibayarkan serta $t$ adalah tingkat pajak yang dibayarkan perusahaan. Laba ditahan (Retention Rate) merupakan ratio yang menunjukkan tingkat keuntungan yang tidak dibagikan kepada pemegang saham sebagai dividen. Tingkat laba yang tidak dibagikan sebagai dividen ini menambah jumlah modal sendiri dan tentunya memberikan pengaruh yang positif terhadap tingkat pertumbuhan modal sendiri. Brigham (1992) menyatakan bahwa laba ditahan adalah penghasilan perusahaan yang ditahan dan tidak dibayarkan sebagai dividen. Penghasilan atau laba yang ditahan bersama dengan cadangan depresiasi merupakan dana yang berasal dari 
operasi perusahaan, sedangkan utang, saham preferen, dan saham biasa merupakan sumber dana yang berasal dari luar perusahaan. Perbedaan utama antara laba yang ditahan dan ketiga sumber dana eksternal tersebut adalah laba yang ditahan dalam jumlah yang terbatas, dan dana tersebut tidak perlu dicari dari luar. Pembelanjaan yang berasal dari laba ditahan ini mengurangi dividen yang dibayarkan kepada pemilik saham. Hal tersebut berarti laba yang ditahan yang tersedia tergantung tidak hanya pada penghasilan perusahaan, namun juga pada kebijakan dividen perusahaan. Apabila perusahaan mengurangi jumlah dividen maka akan meningkatkan laba yang ditahan. Laba yang ditahan di masa yang akan datang diharapkan dapat meningkatkan jumlah dividen yang dibayarkan. Apabila perusahaan menggunakan utang untuk membelanjai operasi perusahaan maka perusahaan harus membayar bunga pinjaman yang tentunya akan mengurangi penghasilan perusahaan dan akhirnya akan mengurangi jumlah dividen yang dibayarkan. Apabila perusahaan mengeluarkan saham preferen atau saham biasa baru maka saham baru tersebut juga harus membayarkan dividen untuk saham yang baru seperti saham yang lama.

\section{Kebijakan Dividen}

Levy dan Sarnat (1988) menyatakan bahwa dividen merupakan sejumlah uang dari sebagian penghasilan yang dibayarkan kepada pemegang saham. Dividen dapat pula diberikan dalam bentuk aktiva lain. Teori dividen yang tidak relevan (Dividend Irrelevan Theory) kebijakan dividen tidak berpengaruh terhadap kemakmuran pemegang saham. Teori ini tidak berlanjut lama karena tidak sesuai dengan kenyataannya, karena asumsi yang dipakai pada kenyataannya tidak dapat dipenuhi sehingga muncul teori-teori lain. Investor akan lebih merasa aman apabila memperoleh pendapatan dividen daripada menunggu capital gain. Faktorfaktor yang mempengaruhi dividend payout antara lain: Tax Clientele, Transaction Cost and the Residual Theory Of Dividend, Growth, Signaling, Agency Theory And Dividends, dan Managerial Consideration.

\section{Penelitian Terdahulu}

Hansen, Kumar, dan Shome (1994) dalam penelitiannya memfokuskan pada keuntungan, dimungkinkannya pemantauan yang berhubungan dengan tingginya dividen sebagai penjelasan adanya kebijakan pembayaran yang mahal pada perusahaan utilitas listrik. Menurut rasionalitas pemantauan (monitoring rasionality), suatu perusahaan akan membayar dividen dengan mahal untuk meningkatkan kemungkinan menjual saham biasa. Penerbitan modal baru akan memicu penyelidikan terhadap pembuat keputusan perusahaan oleh bank-bank investasi, bursa saham, Securities Exchange Committee, dan pemasok modal baru sehingga tingginya dividen akan mendisiplinkan pembuat keputusan. Pengujian terhadap 400 perusahaan industri yang menjadi sampel penelitian dengan data yang diambil dari COMPUSTAT pada dua periode yang terpisah yaitu tahun 1981 sampai tahun 1985 dan tahun 1986 sampai tahun 1990, menemukan hasil yang mendukung rasionalitas pemantauan, mengurangi biaya keagenan dan meningkatkan nilai perusahaan.

Papaioannou dan Savarese (1994) menguji perubahan pembayaran dividen atas 283 perusahaan sampel yang didapat dari daftar FORTUNE 500 dan FORTUNE 50 untuk data relevan kuartal ketiga tahun 1983 sampai kuartal tahun pertama tahun 1991. Hasil penelitian menunjukkan bahwa perusahaan dengan rasio pembayaran rendah dan menengah dalam periode sebelum Tax Reform Act meningkatkan rasio pembayarannya secara signifikan setelah tahun 1986, namun perusahaan dengan rasiopembayaran tinggi menurunkan rasio pembayarannya secara signifikan. Hasil ini konsisten dengan pandangan manajemen yang ditanggapi untuk menyusun 
kembali tingkat pajak atas dividen (dividend payout ratio). Secara keseluruhan studi ini memberikan bukti atas penyebab atas perubahan pajak pada kebijakan dividen dalam periode setelah Tax Reform Act (post-TRA period).

Sterk dan Vanderberg (1990) melakukan survei pada Citizens Utilities Stock yang diperdagangkan pada over-the counter (OTC), menggunakan harga harian dari The Dow Jones New Retrieval Service atau dari Standard \& Poor's OTC Daily Stock Prices untuk periode dari Januari 1985 sampai januari 1987 dan memperoleh data dividen dari Mooddy's Dividend Record, hasil survey mengindikasikan bahwa para kepala bagian keuangan (Corporate chief financial officers) percaya bahwa kebijakan dividen mempengaruhi harga saham. Satu faktor yang menyebabkan masalah kebijakan dividen adalah kemungkinan efek pajak. Kesimpulan yang diambil menyatakan pasar saham Citizens Utilities mengindikasikan adanya kebijakan pajak mempengaruhi harga pasar.

Jensen dan Johnson (1995) melakukan studi dengan 268 observasi yang terdiri dari 218 kasus penurunan dividen dan 50 kasus pengabaian dividen, dengan data keuangan yang diperoleh dari COMPUSTAT tape. Studi ini menemukan bahwa penurunan dividen akan diikuti dengan dengan penurunan pengeluaranpengeluaran perusahaan pada aktiva tetap serta biaya penelitian dan pengembangan, menjual aktiva tetap lebih banyak, mengurangi karyawan dan mengurangi aktivitas keuangan eksternal. Tindakan ini dapat merusak posisi kompetitif jangka panjang perusahaan dalam industrinya dan dapat menjelaskan tanggapan negatif atas suatu perolehan penurunan dividen.

Cruthley dan Hansen (1989) melakukan penelitian atas 603 sampel perusahaan industrial COMPUSTAT file dari tahun 1981 sampai tahun 1985. Hasil penelitian ini mendukung penjelasan teori keagenan atas bagaimana manajer perusahaan menentukan kepemilikan saham biasanya, tingkat utang perusahaan, dan dividen perusahaan. Khususnya ditemukan bahwa kepemilikan saham biasa manajer berhubungan terbalik dengan tingkat diversifikasi saham biasa. Tingkat kepemilikan, tingkat utang dan dividen dipilih secara berpasangan oleh manajer untuk mengendalikan biaya keagenan.

Huberman (1990) melakukan penelitian dengan mengkonstruksikan model intertemporal atas saham-saham perusahaan yang diperdagangkan investor. Maksud dari penelitian ini adalah untuk menunjukkan kebijakan dividen mempengaruhi kesejahteraan investor dan harga saham jika biaya transaksinya mahal, namun hasilnya bertentangan. Walaupun biaya transaksi dimasukkan dalam model penelitian ini, pembayaran dividen tidak berpengaruh pada kesejahteraan Shareholder Preferences and dividend Policy" dengan membangun teori alternatif antara prosedur-prosedur dan distribusi kas dari perusahaan kepada pemegang saham. Walaupun ada perlakuan istimewa pajak atas capital gain untuk investor individu, menunjukkan mayoritas pemegang saham perusahaan dapat mendukung pembayaran dividen untuk distribusi yang kecil. Untuk distribusi yang besar, suatu pembelian kembali saham di pasar terbuka sepertinya lebih disukai oleh mayoritas pemegang saham dan ini didominasi oleh tender offer.

Kale dan Noe (1990) melakukan penelitian dengan menyajikan model dua periode dimana dividen menandakan stabilitas arus kas perusahaan, ditampilkan bahwa perusahaan dengan arus kas lebih stabil akan membayar dividen yang lebih besar, kondisi cateris paribus, peningkatan laba perusahaan yang akan dicapai perusahaan untuk menerbitkan modal dan membayar biaya penjamin. Model signifikan ini digunakan untuk memperoleh pengujian empiris perbandingan statis atas tingkat dividen dengan mematuhi karakteristik-karakteristik perusahaan yang diteliti seperti beta perusahaan, komponen tidak sistematis atas varian arus kas, harapan 
tingkat laba, biaya penerbitan surat berharga dan tujuan-tujuan manajemen.

Mars dan Merton (1987) mengembangkan suatu model proses dividen pasar modal secara keseluruhan. Hasil penelitiannya menunjukkankan bahwa dividen secara keseluruhan dapat menunjukkan perilaku sistematis time series yang memberikan bukti bahwa teori perusahaan tertentu yang ketat atas dividen (dividen puzzle).

Kao dan Wu (1994) melakukan penelitian dengan sampel purpose 454 perusahaan, data diambil dari COMPUSTAT tape untuk periode tahun 1965 sampai tahun 1986. Penelitian ini merupakan perluasan dari penelitian Mars dan Merton (1987). Hasilnya menandakan bahwa perubahan dividen merefleksikan perubahan laba yang diharapkan dan tidak diharapkan. Terdapat bukti bahwa efektifitas dividend signaling bergantung pada karakteristik khusus perusahaan dan berhubungan terbalik dengan risiko sistematis perusahaan, pembiayaan modal eksternal, dan ukuran perusahaan serta berhubungan positif dengan investasi bersih dan tingkat perataan dividen.

\section{Hipotesis}

Melihat faktor-faktor yang memang dianggap mempengaruhi dividend payout dan laju pertumbuhan modal sendiri sesuai dengan kondisi Indonesia, peneliti memilih variabel yang digunakan antara lain: Return On Assets, Return on Investment, laba ditahan dan Agency Cost of Debt:

Hipotesis 1: Pembayaran dividen (dividend payout) dan pertumbuhan modal sendiri saling mempengaruhi secara signifikan.

Hipotesis 2: Return on Assets mempengaruhi pembayaran dividend (dividends payout) secara signifikan.
Hipotesis 3: Agency Cost of Debt mempengaruhi pembayaran dividen (dividends payout) secara signifikan.

Hipotesis 4: Laba ditahan mempengaruhi pertumbuhan modal sendiri secara signifikan.

Hipotesis 5: Return on Investment mempengaruhi pertumbuhan modal sendiri secara signifikan.

\section{METODE PENELITIAN}

\section{Sampel, Data dan Sumber Data}

Sampel diambil secara purposive sampling dari perusahaan-perusahaan yang listing di Bursa Efek Indonesia. Data yang diambil adalah data sekunder yang diterbitkan secara bulanan dan tahunan oleh PT Bursa Efek Indonesia dan Badan Pengawas Pasar Modal antara lain: Perusahaanperusahaan yang membagikan dividen kas dari tahun 2009 sampai dengan tahun 2013; laporan keuangan tahunan perusahaan yang go public di Bursa Efek Indonesia, terdiri dari neraca, perhitungan rugi laba/ Sumber data diperoleh dari: JSX Fact Book; JSX Statistik tahunan; JSX Statistik Bulanan; Laporan Keuangan Tahunan dari masing-masing emiten. Saham perusahaan yang dijadikan sampel aktif ditransaksikan selama periode pengamatan. Kriteria aktif berdasarkan surat edaran BEJ No. SE-03/BEJ III/ I/1994 yang menyatakan bahwa saham dinilai aktif jika frekuensi perdagangan selama tiga bulan sebanyak 75 kali atau lebih (Atmanasakos, 1996) diambil 72 saham teraktif dengan laporan keuangan lengkap yang diperlukan selama periode pengamatan.

\section{Identifikasi dan Pengukuran Variabel}

Variabel endogen dalam penelitian ini terdiri dari dua variabel yaitu: a) Pembayaran Dividen (dividen payout), merupakan nilai logaritma dari jumlah rata-rata pembayaran dividen tahun 2009 sampai tahun 2013. b) 
Tingkat pertumbuhan modal sendiri, diukur melalui pertumbuhan equity yaitu merupakan nilai logaritma. Aktiva akhir tahun dibagi dengan logaritma awal tahun dengan notasi $\mathrm{G}$, dengan perumusan sebagai berikut: $\mathbf{G}=\Delta \mathbf{E} / \mathbf{E}_{\mathbf{t}-1}$

Adapun variabel eksogen (exogenous variable) dalam penelitian ini terdiri dari 4 variabel antara lain:

a. Laba dengan proksi ROI, yaitu kemampuan perusahaan dalam menghasilkan laba dari investasi yang ditanamkan, dengan perumusan:

\section{ROI $=$ EAT/TOTAL ASSETS}

b. Laba dengan proksi ROA, yaitu merupakan kemampuan perusahaan dalam menghasilkan laba dari investasi yang ditanamkan, dengan perumusan:

\section{ROA $=$ EBIT $/$ T ASSETS}

c. Laba ditahan dengan proksi plowback ratio, yaitu merupakan tingkat laba yang ditahan dengan perumusan:

\section{B $=\Delta$ LABA DITAHAN/EAT}

d. Agency Cost of Debt dengan proksi net plant dibagi dengan total aset yang digunakan untuk mengurangi masalah keagenan antara pemegang saham dengan pemegang obligasi, dengan perumusan sebagai berikut:

\section{AGENCY $=$ NET PLAN/TOTAL ASSETS}

\section{Perumusan Model dan Pengujian Hipotesis}

Untuk mengetahui apakah terdapat hubungan yang saling mempengaruhi antara pembayaran dividen dan pertumbuhan modal sendiri perusahaan digunakan model persamaan strutural (structural equation models). Analisis statistik ini mengestimasi beberapa persamaan regresi yang terpisah, tetapi saling berhubungan, secara bersamaan (simultaneously).

Langkah-langkah Structural Equation Modelling yang dilakukan adalah: 1) mengembangkan model teoritis; 2) menyiapkan path diagram, 3) menjabarkan path diagram antara lain menterjemahkan structural equation, 4) menspesifikasi measurement model, dan identifikasi korelasi antar constructs dan indikator, 5) menyiapkan dan memasukkan input, 6) menilai identifikasi model dan mengevaluasi goodness-of-fit index (GFI), dan 7) Interpretasi model. Pengujian kesesuaian model dilakukan dengan mendasarkan pada tiga kriteria sebagai berikut: pertama, model Absolute Goodness of Fit yaitu terdiri dari 3 pengujian antara lain: $\mathrm{X}^{2}$ (Chi-Square), GFI (Goodness Of Fit), RMR (Root Mean Square Residual). Hair (1998) menyatakan bahwa tingkat kesesuaian yang disarankan untuk indikator $\mathrm{X}^{2}$ adalah nilai $\mathrm{p}$ (row) untuk GFI adalah nilai sebesar 0.90 atau lebih. Untuk indikator RMR adalah nilai lebih kecil dari 1 dianggap diterima kedua, Incremental Goodness of Fit yaitu terdiri dari 2 pengujian yaitu TLI (Tucker Lewis Index) dan NFI (Normal Fit index). Tingkat kesesuaian yang disarankan untuk indikator TLI adalah 0.90 atau lebih, sedangkan indikator NFI sebesar 0,90 atau lebih, dan ketiga, Parsimony Goodness of Fit diukur dengan pengujian AGFI (Adjusted Goodness of Fit Index). Tingkat kesesuaian yang disarankan untuk indikator AGFI 0.90 atau lebih. Arbuckle (1997) menyatakan bahwa untuk menentukan signifikansi setiap coefficient path dapat dilihat melalui critical ratio menyatakan bahwa koefisien path yang memiliki nilai critical ratio harus lebih besar dari 1.96.

Model penelitian dengan menggunakan model persamaan struktural seperti disajikan dalam Gambar 1 berikut: 


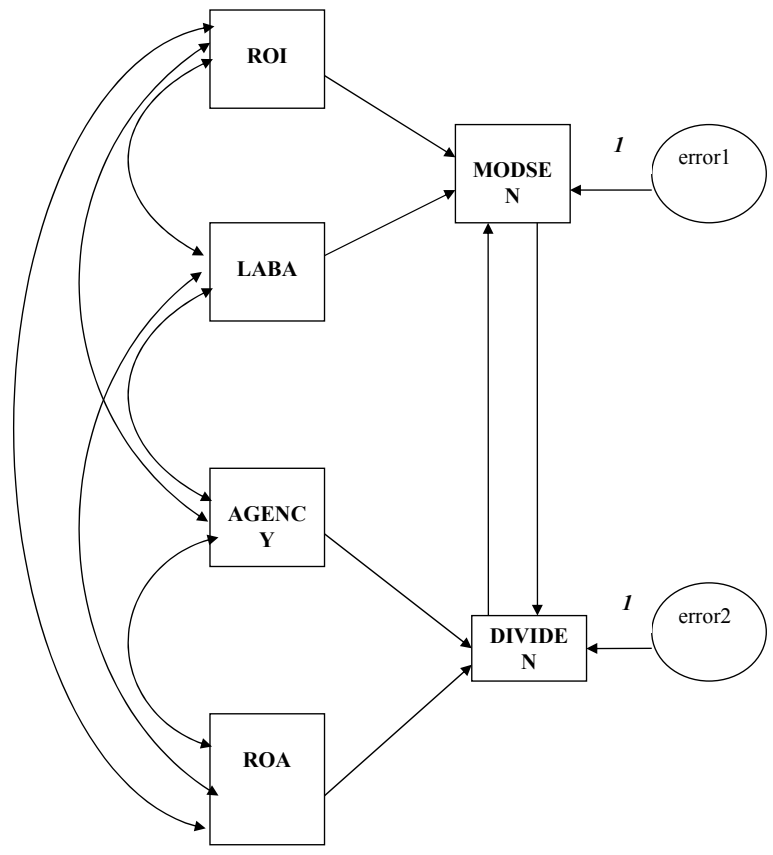

\section{Gambar 1 \\ Model Penelitian}

\section{Keterangan gambar:}

Jumlah observed variable sebanyak 6 antara lain terdiri dari:

1. Observed endogenous yaitu modal sendiri (MODSEN) dan pembayaran dividen (DIVIDEN)

2. Empat observed exogenous yaitu Return on Investment (ROI), Laba ditahan (LABA) Agency Cost of Debt (AGENCY), dan Return on Assets (ROA).

3. Unobserved exogenous terdiri dari disturbance term (error 1 dan error 2)

Gambar 1 tersebut apabila dibuat perumusan hipotesis dalam persamaan adalah sebagai berikut:

$$
\begin{aligned}
& Y_{1}=\alpha_{1} X_{1}+\alpha_{2} X_{2}+\alpha Y_{2} \\
& Y_{2}=\alpha_{3} X_{3}+\alpha_{4} X_{4}+\alpha Y_{1}
\end{aligned}
$$

\section{Keterangan:}

X Variabel eksogen

Y : Variabel Endogen
A : Konstanta

$\mathrm{Y}_{1} \quad$ : Pembayaran Dividen (Dividen Payout)

$\mathrm{Y}_{2} \quad$ Pertumbuhan Modal Sendiri

$\mathrm{X}_{1} \quad$ : Return on Assets (ROA)

$\mathrm{X}_{2}$ : Agency (Agency Cost of Debt)

$\mathrm{X}_{3}$ : Return On Investment (ROI)

$\mathrm{X}_{4} \quad$ : Laba Ditahan (Payback Ratio)

\section{HASIL PENELITIAN DAN PEMBAHASAN}

Analisis ini bertujuan untuk mengetahui pengaruh timbal balik antara pembayaran dividen (dividen payout) dan pertumbuhan modal sendiri. Disamping itu analisis ini bertujuan untuk mengetahui hubungan dan pengaruh dari faktorfaktor yang mempengaruhi pembayaran dividen dan pertumbuhan modal sendiri perusahaanperusahaan manufaktur yang listing sejak tahun 2009 di Bursa Efek Indonesia.

Hasil pengujian model ditunjukkan dalam Gambar 2 berikut:

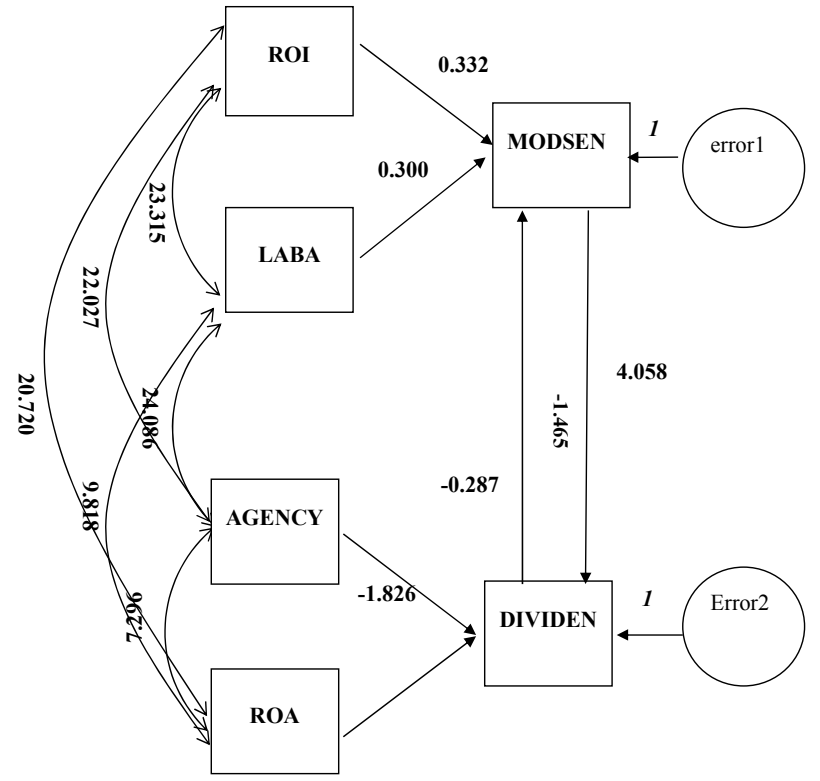

Sumber: Data diolah

Gambar 2

Hasil Pengujian Dengan Koefisien Estimasi Setiap Path 
Untuk menentukan signifikansi setiap koefisien path tersebut dapat dilihat melalui nilai critical ratio. Arbuckle (1992) menyatakan bahwa koefisien path yang memiliki nilai critical ratio lebih besar dari 1, 96 menunjukkan bahwa koefisien path tersebut signifikan pada taraf $5 \%$. Nilai koefisien path dapat dilihat dalam Tabel 1 berikut:

\section{Tabel 1}

Hasil pengujian: Nilai Koefisien Path

\begin{tabular}{|c|l|c|}
\hline No & \multicolumn{1}{|c|}{ Variabel } & $\begin{array}{c}\text { Nilai Koefisien } \\
\text { Path }\end{array}$ \\
\hline 1 & MODSEN - ROI & 0.332 \\
\hline 2 & MODSEN - LABA & 0.300 \\
\hline 3 & DIVIDEN - AGENCY & -0.287 \\
\hline 4 & DIVIDEN - ROA & -1.826 \\
\hline 5 & MODSEN - DIVIDEN & -1.465 \\
\hline 6 & DIVIDEN - MODSEN & 4.058 \\
\hline
\end{tabular}

Sumber: data diolah

Adapun nilai critical ratio tersebut dapat dilihat dalam Tabel 2 berikut:

Tabel 2

\section{Hasil pengujian: Nilai Critical Ratio}

\begin{tabular}{|c|l|c|}
\hline No & \multicolumn{1}{|c|}{ Variabel } & Nilai Koefisien Path \\
\hline 1 & MODSEN - ROI & $2.533^{*}$ \\
\hline 2 & MODSEN - LABA & 1.872 \\
\hline 3 & DIVIDEN - AGENCY & -1.391 \\
\hline 4 & DIVIDEN - ROA & $-2.554^{*}$ \\
\hline 5 & MODSEN - DIVIDEN & -1.854 \\
\hline 6 & DIVIDEN - MODSEN & $-2.749^{*}$ \\
\hline
\end{tabular}

Sumber: data diolah

*Signifikan of level 5\%

Berdasarkan nilai koefisien path dalam Tabel 1 dan melihat tingkat signifikasinya nilai critical ratio pada Tabel 2 maka dapat dilihat bahwa 3 dari 6 koefisien path signifikan pada taraf 5\% atau nilai critical ratio lebih besar dari 1.96 (Hair, 1998). Hal tersebut menunjukkan uji model berikut:
1. Variabel endogen pertumbuhan modal sendiri dengan proksi MODSEN dan variable eksogen profitabilitas dengan proksi ROI mempunyai pengaruh positif signifikan. Hal ini bisa dilihat dari nilai koefisien path sebesar 2.533 yaitu signifikan pada tingkat 5\%. Hasil penelitian ini konsisten dengan hasil penelitian yang dilakukan Surwanti (1996) yang menemukan bahwa pengaruh return on investment terhadap tingkat pertumbuhan modal sendiri bersifat positif. Artinya bahwa setiap peningkatan variable return on investment akan disertai dengan peningkatan variabel tingkat pertumbuhan modal sendiri sebesar koefisien estimasinya.

2. Variabel endogen pertumbuhan modal sendiri dengan proksi MODSEN dan variabel eksogen laba ditahan dengan proksi LABA mempunyai pengaruh positif namun tidak signifikan. Hal ini disebabkan karena nilai koefisien estimasi sebesar 0.300 dengan nilai critical ratio 1.872 lebih kecil dari nilai yang disyaratkan 1.96. Hasil penelitian ini konsisten dengan hasil penelitian dilakukan Surwanti (1996) yang menemukan bahwa laba ditahan mempunyai pengaruh positif dengan pertumbuhan modal sendiri. Artinya setiap peningkatan variabel laba ditahan akan disertai dengan peningkatan variabel tingkat pertumbuhan modal sendiri sebesar koefisien estimasinya.

3. Variabel endogen pembayaran dividen dengan proksi DIVIDEN dan variabel eksogen agency cost of debt dengan proksi AGENCY mempunyai pengaruh negatif namun tidak signifikan. Hal ini disebabkan karena nilai koefisien estimasi sebesar -0.287 dengan nikai critical ratio -1.391 adalah lebih kecil dari nilai yang disyaratkan sebesar 1.96. Hasil penelitian ini konsisten dengan hasil penelitian yang dilakukan Sugiarto (1997) yang menemukan bahwa agency cost of debt mempunyai hubungan 
negatif dengan pembayaran dividen. Artinya bahwa jika aktiva yang dapat dijaminkan untuk mengurangi masalah keagenan antara pemegang saham dan pemegang obligasi meningkat maka pembayaran dividen akan menurun. Hasil penelitian ini tidak konsisten dengan hasil penelitian yang dilakukan Alli (1985) yang menemukan bahwa terjadi hubungan positif antara agency cost of debt dengan pembayaran dividen. Perbedaan hasil signifikansi dan arah hubungan antara variabel agency dengan pembayaran dividen ini menunjukan bahwa emiten di Bursa Efek Indonesia belum memperhatikan peran dividen dalam mengurangi masalah keagenan antara pemegang saham dan pemegang obligasi pada saat menentukan besarnya pembayaran dividen (dividen payout).

4. Variabel endogen pembayaran dividen dengan proksi DIVIDEN dan variabel eksogen profitabilitas perusahaan dengan proksi ROA mempunyai pengaruh negatif signifikan. Hal ini dapat dilihat dari besar nilai koefisien estimasi - 1.826 dengan nilai critical ratio sebesar 2.554 signifikan pada tingkat 5\%. Hasil penelitian ini tidak konsisten dengan hasil penelitian yang dilakukan Sugiarto (1997) bahwa terjadi hubungan positif antara return on assets dengan pembayaran dividen, artinya bahwa sama saja return on assets tidak mempunyai pengaruh signifikan terhadap pembayaran dividen atau hubungan positif ini menunjukkan bahwa jika tingkat pengembalian investasi dari aktiva meningkat maka pembayaran dividen akan meningkat. Namun hasil penelitian ini konsisten dengan hasil penelitian yang dilakukan oleh Efendri (1993) yang menggunakan ROI sebagai proksi dari teori dividen sisa yang menyatakan bahwa suatu perusahaan akan membayar dividen hanya jika dana-dana internal tidak seluruhnya digunakan untuk tujuan investasi. Perusahaan yang sedang tumbuh pesat membutuhkan investasi besar sehingga seharusnya perusahaan tersebut untuk membagi dividen serendah mungkin atau berhungan negatif. Sehingga hasil penelitian ini menunjukkan bahwa emiten di Bursa Efek Indonesia telah memperhatikan adanya penyisihan pembayaran dividen untuk pembayaran investasinya.

5. Varibel endogen pertumbuhan modal sendiri dengan proksi MODSEN dan variable eksogen pembayaran dividen dengan proksi DIVIDEN mempunyai pengaruh negatif namun tidak signifikan. Hal ini disebabkan karena nilai koefisien estimasi sebesar -1.465 dengan nilai critical ratio sebesar -1.854 adalah lebih kecil dari nilai yang disyaratkan sebesar 1.96. Hasil penelitian ini konsisten dengan hasil penelitian yang dilakukan oleh Efendri (1993) yang menggunakan hasil pengembalian investasi akan digunakan untuk menambah modal sendiri sebagai proksi dari teori dividen sisa yang menyatakan bahwa suatu perusahaan akan membayar dividen hanya jika dana-dana internal tidak seluruhnya digunakan untuk tujuan investasi. Dikatakan bahwa perusahaan yang sedang tumbuh pesat membutuhkan investasi besar sehingga seharusnya perusahaan tersebut berusaha untuk membagi dividen serendah mungkin atau hubungan negatif. Pengalaman perusahaan membagi dengan tingkat pertumbuhan yang tinggi umumnya mempuntai kebutuhan investasi besar sehingga pembayaran dividen rendah (Myers dan Majluf, 1984). Hasil penelitian ini menunjukkan bahwa di Bursa Efek Indonesia telah memperhatikan adanya penyisihan dana dari penundaan pembayaran dividen untuk pembiayaan investasinya.

6. Variabel endogen pembayaran dividen dengan proksi DIVIDEN dan variabel eksogen pertumbuhan modal sendiri dengan proksi MODSEN mempunyai pegaruh positif 
signifikan. Hal ini dapat dilihat dari nilai koefisien estimasi sebasar 4.058 dengan nilai critical ratio sebesar 2.749 signifikan pada tingkat 5\%. Hasil penelitian ini tidak konsisten dengan hasil penelitian yang dilakukan Myers dan Majluf (1984) menyatakan bahwa perusahaan dengan tingkat pertumbuhan yang tinggi mempunyai kebutuhan investasi yang besar sehingga pembayaran dividennya rendah. Untuk menguji tingkat kesesuaian model penelitian ini menggunakan criteria pengujian model sesuai yang disyaratkan Bollen, Kenneth (1989), Hair (1998), dan Arbuckle (1997). Berikut disajikan hasil Indikator Goodness of Fit Index (GFI) antara tingkat kesesuaian yang disarankan hasil uji model penelitian dalam Tabel 3:

Tabel 3

Hasil Indikator Goodness of Fit (GFI)

\begin{tabular}{|l|l|l|l|}
\hline Indikator GFI & $\begin{array}{c}\text { Tingkat kesesuaian } \\
\text { Yang disarankan }\end{array}$ & $\begin{array}{c}\text { Model } \\
\text { Penelitian }\end{array}$ & Keputusan \\
\hline Absolut : & & & \\
\hline P - value & Min 0.50 & 0.081 & Diterima \\
\hline GFI & 0.90 atau lebih & 0.969 & Diterima \\
\hline RMR & $<1$ & 0.836 & Diterima \\
\hline Incremental : & & & \\
\hline TLI & 0.90 atau lebih & 0.862 & Marginal \\
\hline NFI & 0.90 atau lebih & 0.955 & Diterima \\
\hline Parsimony & & & \\
\hline AGFI & 0.90 atau lebih & 0.783 & Marginal \\
\hline
\end{tabular}

Sumber: Data diolah

Model persamaan struktural digunakan dalam penelitian ini untuk menguji seluruh pengaruh faktor fundamental dalam struktur model. Persamaan struktural yang baik karena Chi-square signifikan pada p sebesar 0.081. Bollen (1989) menyatakan bahwa semakin tinggi nilai probabilitas dari Chi-square statistic suatu model maka semakin baik model yang diajukan tersebut. Hasil penelitian ini menunjukkan bahwa nilai $\mathrm{p}$ sebesar 0.0181 adalah diatas tingkat minimum yang disyaratkan $\mathrm{p}$ sebesar 0.05 (Hair, 1998). Tabel 3 terlihat bahwa keenam Indicator Goodness of Fit dapat memenuhi kriteria tingkat kesesuaian yang disarankan yaitu nilai Goodness of Fit Index sebesar 0.969, nilai Root Mean Residual sebesar 0.836, Normed Fit Index sebesar 0.955 Adjusted Goodness of Fit Index sebesar 0.783, Tucker Lewis Index (0.862), sehingga dapat diterima karena melebihi tingkat kesesuaian yang disyaratkan. Berdasarkan Tabel 3 dapat dijelaskan bahwa $\mathrm{p}=0.081>0.05$ secara stastistik mengindikasikan kecocokan yang baik., melebihi tingkat nilai yang direkomendasikan yaitu sebesar 0.90 (Hair, 1998). Hal ini mengindikasikan kecocokan yang baik antara data dengan model penelitian yang diajukan.

Berdasarkan hasil ulasan uji stastistik diatas diketahui bahwa dari lima hipotesis yang diajukan ternyata tiga diantaranya terbukti dan dua sisanya tidak terbukti antara lain sebagai berikut:

1. Hipotesis 1, yang menyatakan bahwa pembayaran dividen dan pertumbuhan modal sendiri saling mempengaruhi secara signifikan positif adalah diterima. Hasil ini ditunjukkan bahwa pembayaran dividen dipengaruhi oleh pertumbuhan modal sendiri dengan koefisien pengaruh sebesar 4.058 dan signifikan pada alpha 0.50 dengan nilai critical rationya sebesar 2.749 adalah lebih besar dari nilai yang disyaratkan sebesar 1.96.

2. Hipotesis 2, yang menyatakan bahwa profibilitas dengan proksiROAmempengaruhi pembayaran dividen secara negatif signifikan adalah terbukti. Karena nilai koefisien pengaruh sebesar -1.826 dan signifikan pada alpha $5 \%$ dengan nilai critical ratio sebesar -2.554 adalah lebih besar dari 1.96 .

3. Hipotesis 3, yang menyatakan bahwa agency cost of debt dengan proksi AGENCY mempengaruhi pembyaran dividen secara negatif signifikan adalah tidak terbukti. Karena nilai koefisiensi pengaruh sebesar - 
0.287 adalah tidak signifikan pada alpha 5 $\%$ karena dengan nilai critical ratio sebesar -1.391 lebih kecil dari 1.96.

4. Hipotesis 4, yang menyatakan bahwa laba ditahan (retention rate) dengan proksi LABA mempengaruhi pertumbuhan modal sendiri secara positif signifikan adalah tidak terbukti. Karena nilai koefisiensi pengaruh sebesar 0.300 adalah tidak signifikan pada alpha 5 $\%$ karena dengan nilai critical ratio sebesar 1.872 lebih kecil dari 1.96 .

5. Hipotesis 5, yang menyatakan bahwa profitabilitas dengan proksi ROI (return of investment) mempengaruhi pertumbuhan modal sendiri secara positif signifikan adalah terbukti. Nilai koefisien pengaruh sebesar 0.332 adalah signifikan pada alpha 5\% karena dengan nilai critical ratio sebesar 2. 533 lebih besar dari 1.96 .

\section{KESIMPULAN DAN SARAN}

\section{Kesimpulan}

Penelitian ini berhasil mendukung hipotesis 1, hipotesis 2, dan hipotesis 5. Ada beberapa variabel yang selama ini ditengarai sebagai faktor yang mempengaruhi keputusan pembayaran dividen dan pertumbuhan modal sendiri sebagian terbukti dan sebagian tidak. Hal ini ditunjukkan dengan pembuktian berikut:

- Pengaruh positif signifikan antara pembayaran dividen dengan proksi DIVIDEN terhadap pertumbuhan modal sendiri dengan proksi MODSEN.

- Pengaruh negatif signifikan antara profitabilitas dengan proksi ROA terhadap pembayaran dividen dengan proksi DIVIDEN.

- Pengaruh positif signifikan antara pembayaran dengan proksi ROI terhadap pertumbuhan modal sendiri dengan proksi MODSEN.

Penelitian ini tidak berhasil mendukung hipotesis 3, dan hipotesis 4. Ada beberapa variabel yang selama ini ditengarai sebagai faktor yang mempengaruhi keputusan pembayaran dividen dan pertumbuhan modal sendiri sebagian terbukti dan sebagian tidak. Hal ini ditunjukkan pembuktian berikut:

- Pengaruh negatif tidak signifikan antara agency cost of debt dengan proksi AGENCY terhadap pembayaran dividen dengan proksi DIVIDEN.

- Pengaruh positif tidak signifikan antara retention rate dengan proksi LABA terhadap pertumbuhan modal sendiri dengan proksi MODSEN.

Untuk menguji tingkat kesesuaian secara menyeluruh indicator Goodness of Fit dapat memenuhi kriteria tingkat kesesuaian yang disarankan yaitu indikator $\mathrm{X}^{2}$ dengan nilai sebesar 6.722, nilai GFI sebesar 0.969, NFI sebesar 0.955 dapat diterima, sehingga dapat dijelaskan bahwa Chi Square $\left(X^{2}=6.722\right)$ dengan degree of freedom sebesar 3 , dan $\mathrm{P}=0.081>0.05$ secara statistik mengindikasikan kecocokan yang baik. Dengan menggunakan alat ukur non statistik seperti GFI (0.969), TLI (0.862) dan NFI (0.955) melebihi tingkat nilai yang yang direkomendasikan yaitu sebesar 0.90 (Hair, 1998). Hal tersebut mengidikasikan mempunyai kecocokan yang baik antara data dengan model penelitian yang diajukan.

\section{Keterbatasan}

Pemakaian variabel dalam penelitian ini hanya mendasarkan padakelengkapan tersedianya data pada Bursa Efek Indonesia, kemungkinan gangguan pada hasil penelitian yang disebabkan oleh tidak terpenuhinya jumlah data maksimal yang diperlukan untuk menganalisa data dengan menggunakan SEM. Untuk menggunakan analisa ini disyaratkan tersedianya data minimum 50 data dan maksimum 200 data (Hair, 1998) sedangkan sampel data yang penulis pergunakan dalam penelitian ini adalah sebanyak 72 sampel. 


\section{Saran}

Kelemahan dan keterbatasan penelitian ini maka perlu penelitian berikutnya dengan mengambil sampel yang lebih banyak. Disamping sampel yang lebih banyak akan lebih baik apabila variabel pembayaran dividen perlu dimasukkan atribut untuk mengelompokkan ukuran perusahaan manufaktur kedalam perusahaan manufaktur besar dan perusahaan manufaktur kecil. Sampel yang lebih banyak dan memasukkan atribut tambahan, serta adanya pengklasteran akan mampu mengelompokkan perusahaan-perusahaan menjadi perusahaan skala besar dan kecil. Hal tersebut penting dilakukan untuk mengetahui apakah bagi perusahaan dengan skala kecil sebaiknya membagikan dividennya apa tidak. Atau sebaliknya apakah perusahaan manufaktur dalam skala besar tingkat pertumbuhan modal sendirinya meningkat atau tidak.

\section{DAFTAR PUSTAKA}

Alli, Khan, dan Ramires, 1985, "The Impact of Initiating Dividend Payment on Shareholders Wealth", Journal of Business 56.

Arbuckle, J. 1997. Amos Version 18 Chicago, IL: SmallWarters Corporation.

Brigham, Eugene F., 1996. Intermediate Financial Management. Tifth Edition. The Dryden Press.

Crutchley dan Hansen, 1989, "A Test of The Agency Theory of Managerial Ownership, Corporate Leverage and Corporate Dividends", Journal of Finance. March.

Hair. J F,.Jr.,R.E.Anderson,R.I., Tatham and W.C. Black 1998. Multivariate data Analysis: with Readings. Indianapolis,,
Fifth Edition: Macmillan Publishing Company.

Hansen, Kumar dan Shome. 1994, "Dividend Policy and Corporate Monitoring: Evidence from the regulated".

Huberman, 1990, "Dividend Neutrality with Transaction Cost", Journal of Financial Economic 21.

Jensen dan Johnson,1995, "The Dynamic of Corporate Dividend Reduction", Journal of Finance.May.

Indonesia Stock Exchange, Fact Book (2012 s/d 2014) ., JSX Statistic (2012 s/d 2014)

s/d 2014) ., JSX Monthly (2012

Marsh dan Merton. 1987. 'Dividend Behavior for The Aggregate Stock Market”, Journal of Finance March.

Myers. S dan Majlul 1984. "The Capital Structure Puzle”, Journal of Finance. Vol 39. July.

Papaioanou dan Savarese. 1994. "Corporate Dividend Policy Response to the Tax Reform Act of 1986", Journal of Financial Economic 5.

Slerk dan Vadenberg. 1990, "The Market valuation of Cash Dividends and The Tax Differential Theory of Dividend Policy; A Case Revisited“, Journal of Financial Economics 32.

Sugiarto. E, 1997, "Analisis faktor-faktor yang mempengaruhi Dividend Payout Ratio".

Surwanti, A., 1996, Analisis faktor-faktor yang mempengaruhi Pertumbuhan Modal Sendiri Pada Bursa Efek Jakarta, Tesis, Pascasarjana. UGM. Yogyakarta. 